\title{
Lipase Production From Thermophilic Bacteria Using Waste Frying Oil As Substrate
}

\author{
Elanur TUYSUZ1, Mustafa Ozkan BALTACí1, Hakan OZKAN1, Mesut TASKIN¹, Ahmet ADIGUZEL1 \\ ${ }^{1}$ Department of Molecular Biology and Genetics, Faculty of Science, Ataturk University, Erzurum, Turkey
}

(Alınış / Received: 08.01.2019, Kabul / Accepted: 24.10.2019)

\section{Keywords}

Bacillus licheniformis,

lipase,

waste frying oil,

production

\begin{abstract}
Lipases are widely used in textile, food, medical and chemical industries. The present study was performed to produce lipase from thermophilic bacterial strains using waste frying oil as substrate. Among four bacterial strains, Bacillus licheniformis A7 (GenBank accesion number: KC310458) was determined to be the best lipase producer. A frying oil concentration of $40 \mathrm{~mL} / \mathrm{L}$, temperature of $55{ }^{\circ} \mathrm{C}$, initial $\mathrm{pH}$ of 6.0 and incubation time of $72 \mathrm{~h}$ were found to be optimal for lipase production from Bacillus sp. Under the optimal culture conditions, the maximum cell growth and lipase activity were determined as $2.2190 \mathrm{D} 600 \mathrm{~nm}$ and $1607 \mathrm{U} / \mathrm{L}$, respectively.
\end{abstract}

\section{Substrat Olarak Atık Kızartma Yağı Kullanarak Termofilik Bakterilerden Lipaz Üretimi}

Anahtar Kelimeler

Bacillus licheniformis, Lipaz,

Atık kızartma yağı, üretim

\begin{abstract}
Özet: Lipazlar tekstil, gıda, tıp ve kimya endüstrilerinde yaygın olarak kullanılmaktadır. Bu çalışmada, substrat olarak atık kızartma yağı kullanılarak termofilik bakteri sușlarından lipaz üretimi gerçekleștirildi. Dört bakteri sușu arasında, Bacillus licheniformis A7 (GenBank numarasi: KC310458) en iyi lipaz üreticisi olarak belirlenmiștir. $40 \mathrm{~mL}$ / L'lik bir kzzartma yağı konsantrasyonu, $55^{\circ}$ C sıcaklık, başlangıç pH 6.0 ve 72 saat inkübasyon süresi, Bacillus sp. Optimum kültür koşulları altında, maksimum hücre büyümesi ve lipaz aktivitesi, sırasıyla 2.219 0D600nm ve $1607 \mathrm{U} / \mathrm{L}$ olarak belirlenmiștir.
\end{abstract}

\section{Introduction}

Today, about 4000 enzymes are known and 200 of them are in commercial use. The main source of the industrial enzymes is microorganisms [1,2]. The use of microorganisms in enzyme production has some important advantages. When compared to plant and animal enzymes, microbial enzymes can show higher stability under extreme conditions and they can be produced in higher quantities. Moreover, the production of microbial enzymes can be carried out at low cost on organic wastes. On the other hand, enzyme producer microorganisms can be screened easily and quickly, and the genetic modifications necessary to increase enzyme production can be performed more easily on microbial cells. [3-5]. Lipases (triacylglycerol hydrolases, EC 3.1.1.3) among industrially important enzymes are considered to be the third largest group in total sales. Lipases can carry out very specific chemical reactions such as interesterification, hydrolysis, esterification and alcoholysis. Due to their high substrate specificity, activity and selectivity, lipases find diverse applications in food, fuel, paper, detergent, dairy, leather cosmetic and pharmaceutical industries [6-8]. Especially thermophilic microorganisms accepted as important source of lipases with biotechnological and/or industrial importance. Lipases produced by thermophilic microorganisms exhibit a highly stable structure at high temperatures in organic solvents and exhibit high activity. Furthermore, these lipases show high resistance against chemical denaturation and may have high activity in alkaline pHs [9-11]. Due to their high activity and stability in alkaline pHs and elevated temperatures, thermophilic lipases are mainly used in detergent industry.

Up to now, it has been demonstrated that bacteria such as Bacillus licheniformis, B. stearothermophilus, Geobacillus thermoleovorans and Thermomonas hydrothermalis can be used as promising sources of thermophilic lipases [12-14]. However, due to the 
industrial and biotechnological importance of thermophilic enzymes, studies on the discovery of new microorganisms that can produce these enzymes are constantly increasing. In order to respond to increasing demands, enzymes must be produced in high amounts. However, the medium cost is considered as an important problem. To solve this problem, agricultural wastes or byproducts are used as cheap enzyme production substrate for microorganisms. For example, waste materials such as coconut cake, mahua cake, lemon peel, coffee husk and soy-residues have been employed as cheap substrates for production of microbial lipases [15-18]. Similarly, investigators have reported that waste-frying oil can be also utilized as cheap substrates in production of microbial lipases $[8,19]$. On the other hand, it has been documented that carbon and nitrogen sources, minerals, $\mathrm{pH}$, temperature, surfactants, inoculum concentration and incubation time can influence lipase production [11, 20-22]. In brief, cheap substrate selection as well as optimizing the culture conditions is accepted as the main factors to be considered in lipase production.

Therefore, the present study was performed to produce lipase from thermophilic bacteria using the waste frying oil as substrate and to increase the enzyme production efficiency by optimizing some culture conditions.

\section{Materials and Method}

\subsection{Preparation of seed cultures for test bacteria}

Four bacterial strains (A7, A8, A10 and 07) isolated from hot springs in our previous studies $[23,24]$ were chosen for the present study. The bacteria activated on tryptic soy agar medium were transferred into 250$\mathrm{mL}$ Erlenmeyer flasks containing $100 \mathrm{~mL}$ of commercial tryptic soy broth medium. The flasks were then left to the incubation in a shaker incubator at 200 rpm for $48 \mathrm{~h}$ at $55^{\circ} \mathrm{C}$.

\subsection{Screening of Lipase producer isolates}

In this stage, four bacteria were screened for their ability to produce lipase. The screening experiments were performed in the medium containing $10 \mathrm{ml} / \mathrm{L}$ frying oil and $3 \mathrm{~g} / \mathrm{L}$ Bushnell Haas salt medium $(\mathrm{pH}$ : 7.0). To do this, the screening medium was inoculated with $1 \mathrm{~mL}(0 D 600 \mathrm{~nm}=1.0)$ of seed culture under aseptic conditions. After the inoculation, the flasks were incubated at $55^{\circ} \mathrm{C}$ with agitation speed of 150 rpm. After $48 \mathrm{~h}$, the lipase activities in the flasks were analyzed and the best lipase producer strain was selected for subsequent experiments.

\subsection{Lipase production with the best strain}

The lipase production with the best strain was performed in $250 \mathrm{~mL}$ flasks containing $100 \mathrm{~mL}$ of the sterilized lipase production medium (the screening medium) described above. During the experiments, different frying oil concentrations (10-70 $\mathrm{mL} / \mathrm{L})$, temperatures $\left(40-70^{\circ} \mathrm{C}\right)$, pHs (5-8) and incubation times (with $12 \mathrm{~h}$ intervals up to $96 \mathrm{~h}$ ) were tested to increase lipase production. In the case of the screening experiments, the lipase production experiments were performed in a shaker at agitation speed of $150 \mathrm{rpm}$.

\subsection{Enzyme assay}

At the end of appropriate incubation period, $1 \mathrm{~mL}$ sample taken from culture was used for the determination of lipase activity. For this purpose, the sample was subjected to the centrifigation (10000 $\mathrm{rpm}$ at $4{ }^{\circ} \mathrm{C}$ ) and the obtained supernatant was employed as enzyme source. The lipase activity was analyzed with some modifications according to the method of Hung et al. [25]. For this, $1 \mathrm{~mL}$ of $0.05 \mathrm{M}$ phosphate buffer ( $\mathrm{pH}$ 8), $0.1 \mathrm{~mL}$ enzyme source (supernatant) and $1 \mathrm{~mL}$ of substrate $(0.013 \mathrm{M} \mathrm{p}$ nitrophenyl palmitate in ethanol) was mixed and the mixture was then incubated for $5 \mathrm{~min}$ at $55^{\circ} \mathrm{C}$. The mixture containing $0.1 \mathrm{~mL}$ of bacteria-free medium instead of the enzyme source (supernatant) was used as the blank. To terminate the reaction, $2 \mathrm{~mL}$ of $0.5 \mathrm{M}$ $\mathrm{Na} 2 \mathrm{CO} 3$ was added to the mixture. Afterwards, the mixture was centrifuged at $10,000 \mathrm{rpm}$ for $10 \mathrm{~min}$. The absorbance of the final mixture was measured at 410 $\mathrm{nm}$. One unit $(\mathrm{U})$ of lipase activity was termed as the amount of enzyme required to hydrolyze $1 \mu \mathrm{mol} / \mathrm{min}$ of p-NPP under the assay conditions. A molar extinction coefficient ( $\varepsilon 410)$ of $13,290 \mathrm{M}-1 \mathrm{~cm}-1$ for p-nitrophenol was used.

\section{Results qnd Discussion}

\subsection{Results \\ Screening of lipase producer isolates}

The screening for new microorganisms is accepted as a very powerful tool for obtaining strains with higher production ability than those already known [26]. Therefore, in the first stage of the present study, four strains of thermophilic bacteria were screened for their lipase production ability under the same culture conditions. As seen data presented in Table 1, the maximum lipase production (289 U/L) was achieved using the strain A7 (Bacillus licheniformis, GenBank accession number: KC310458.1), which was isolated from hot spring in the previous study [23]. Based on these results, this strain was selected for the subsequent experiments.

Table 1. Screening of lipase producer bacteria

\begin{tabular}{lll}
\hline Strain code & Cell growth (OD) & $\begin{array}{l}\text { Lipase activity } \\
\text { (U/L) }\end{array}$ \\
\hline A7 & 1.058 & 289 \\
07 & 0.540 & 117
\end{tabular}




\begin{tabular}{lll}
\hline $\mathrm{A} 8$ & 0.985 & 103 \\
$\mathrm{~A} 10$ & 1.032 & 255
\end{tabular}

$\overline{\text { Screening conditions: Temperature } 55^{\circ} \mathrm{C} \text {, initial } \mathrm{pH}}$ 7.0, frying oil concentration $10 \mathrm{~mL} / \mathrm{L}$, shaking speed $150 \mathrm{rpm}$ and incubation time $48 \mathrm{~h}$.

\subsection{Optimization of lipase production from Bacillus sp. A7}

It is well known that production of microbial enzymes including lipases are significantly affected by culture parameters such as substrate concentration, temperature, $\mathrm{pH}$, surfactants, incubation time, oxygen concentration, shaking speed and incubation time. Therefore, in the present study, some (temperature, oil concentration, $\mathrm{pH}$ and incubation time) of these culture parameters were optimized to enhance lipase production.

It has been noted that oil concentration significantly affects the lipase synthesis in microorganisms [27]. Accordingly, the waste frying oil concentration in this study was also optimized for lipase production. As seen from the results presented in Fig. 1, the lipase production (1336 U/L) and cell growth (1887 OD600 $\mathrm{nm}$ ) reached to the maximum when the experiments were performed at a frying oil concentration of $40 \mathrm{~mL} / \mathrm{L}$, whereas both of them gradually decreased at higher oil concentrations. This inhibitory effect might be due to toxic compounds inside waste frying oil.

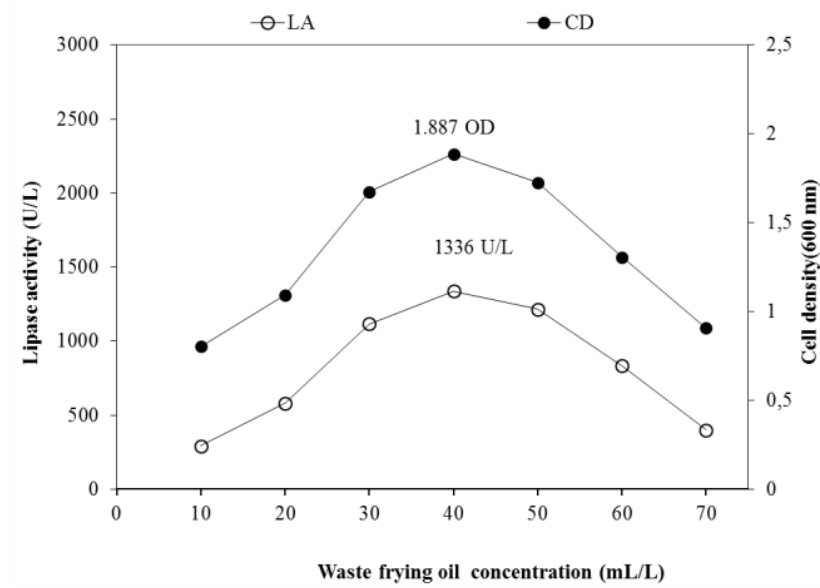

Figure 1. Effect of frying oil concentration on cell growth and lipase synthesis in Bacillus sp. A7. Culture parameters: Temperature $55^{\circ} \mathrm{C}$, initial $\mathrm{pH} 7.0$, shaking speed $150 \mathrm{rpm}$ and incubation time $48 \mathrm{~h}$. LA, lipase activity and CD, cell density.

As seen from Fig. 2, although the bacterium was capable of producing lipase in a wide temperature range from 40 to $70{ }^{\circ} \mathrm{C}$, the lipase production (1334 $\mathrm{U} / \mathrm{L})$ and cell growth (1882 0D600nm) became maximum at $55{ }^{\circ} \mathrm{C}$ by followed at $50{ }^{\circ} \mathrm{C}$. The similar results were also reported in the previous studies in which the lipase production using thermophilic Bacillus strains was performed $[28,29]$.

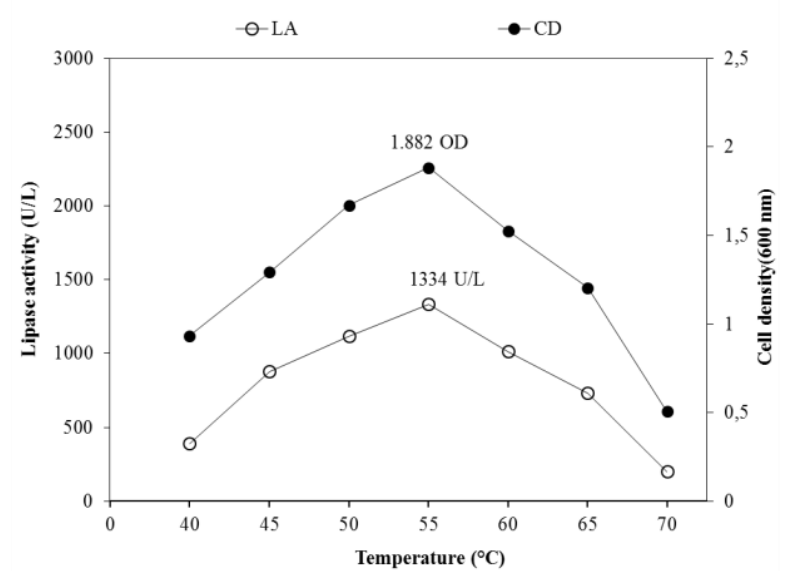

Figure 2. Effect of temperature on cell growth and lipase synthesis in Bacillus sp. A7. Culture parameters:

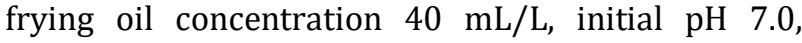
shaking speed $150 \mathrm{rpm}$ and incubation time $48 \mathrm{~h}$. LA, lipase activity and CD, cell density.

The experiments demonstrated that even if the bacterium had the potential to produce lipase in a wide $\mathrm{pH}$ range from 5 to 8 , the maximum cell growth (2.084 0D600nm) and lipase production (1510 U/L) were achieved at pH 6.0 (Fig. 3). This result is contradiction with the fact that neutral or alkaline $\mathrm{pHs}$ are usually more favorable for lipase production from Bacillus strains [30, 31]. However, it can be concluded that this strain can be employed as a novel source of acidic lipases. Considering these results, the following experiments were performed at $55^{\circ} \mathrm{C}$ and $\mathrm{pH}$ 6.0.

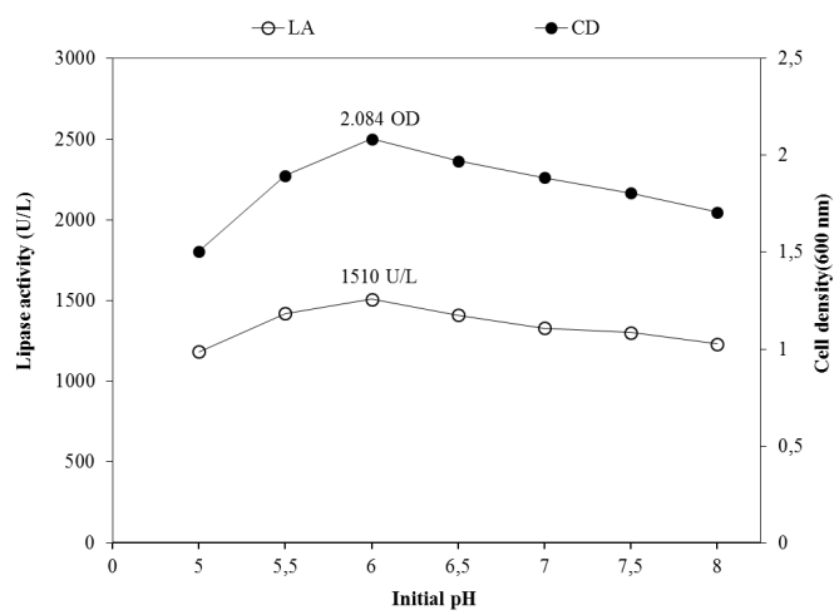

Figure 3. Effect of initial culture $\mathrm{pH}$ on cell growth and lipase synthesis in Bacillus sp. A7 Culture parameters: Temperature $55^{\circ} \mathrm{C}$, frying oil concentration $40 \mathrm{~mL} / \mathrm{L}$, shaking speed $150 \mathrm{rpm}$ and incubation time $48 \mathrm{~h}$. LA, lipase activity and CD, cell density.

The last stage of the study was focused on determining the effect of incubation time on cell growth and lipase production. Fig. 4 indicates that the most increases in cell growth and lipase production occurred within the first $12 \mathrm{~h}$ of cultivation. Fig. 4 also shows that cell growth and lipase activity reached to the maximum levels (respectively, 2.219 0D600nm and $1607 \mathrm{U} / \mathrm{L}$ ) at 
the end of 72th h. On the other hand, the cell growth became stable between 72 and 96 hours but the lipase activity showed a small decrease after 72 th $\mathrm{h}$. This decrease was probably due to the lost of the enzyme stability.

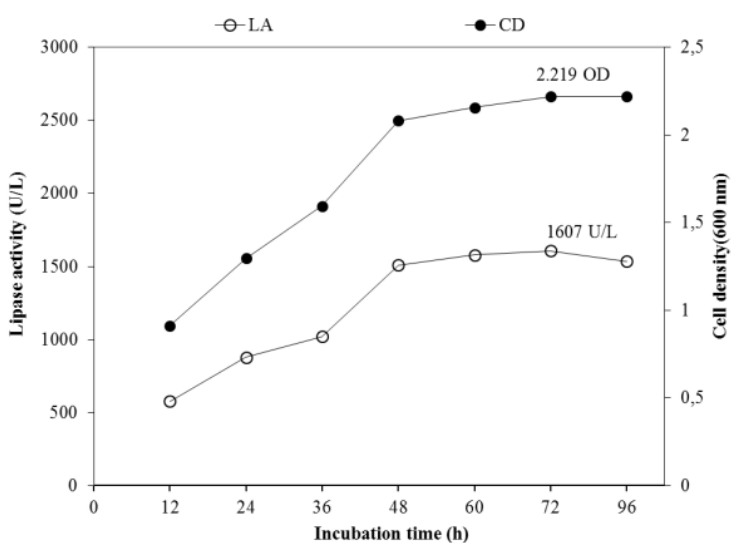

Figure 4. Effect of incubation time on cell growth and lipase synthesis in Bacillus sp. A7. Culture parameters: Temperature $55^{\circ} \mathrm{C}$, frying oil concentration $40 \mathrm{~mL} / \mathrm{L}$, initial pH 6.0 and shaking speed $150 \mathrm{rpm}$. LA, lipase activity and CD, cell density.

\section{Conlusions}

This study revealed that locally isolated thermophilic Bacillus sp. A7 had the potential to produce lipase. Optimization of waste frying oil concentration, temperature, initial $\mathrm{pH}$ and incubation time increased the enzyme production in shaking flask culture of this bacterium. The enzyme may have the potential to use in industrial and biotechnological fields. However, we intend to carry out the purification and characterization of the enzyme in the future studies in order to exploit this potential.

\section{REFERENCES}

[1] R. Sharma, Y. Chisti, U.C. Banerjee, "Production, purification, characterization, and applications of lipases," Biotechnol. Adv. 19, 627-662.,2001.

[2] S.S. Dewan, "Global Markets for Enzymes in Industrial Applications," Welles- ley, MA:BCCResearch, 2014.

[3] D. S. Ribeiro, S.M.B. Henrique, L. S. Oliveira, G. A. Macedo, L. F. Fleuri, "Enzymes in juice processing: a review," Int. J. Food Sci. Technol. 45, 635-641., 2010.

[4] N. Gurung, S. Ray, S. Bose, V. Rai, "A Broader View: Microbial Enzymes and Their Relevance in Industries, Medicine, and Beyond," Biomed. Res. Int, 329121., 2013.
[5] P. Anbu, S.C. Gopinath, A.C. Cihan and B. P. Chaulagain, "Microbial enzymes and their applications in industries and medicine," BioMed research international, 2013.

[6] F. Hasan, A. A. Shah and A. Hameed, "Industrial applications of microbial lipases," Enzyme and Microbial technology, vol. 39(2), pp. 235-251, 2006.

[7] N. A. Soliman,, M. Knoll, Y. R.Abdel-Fattah, R.D. Schmid and S. Lange, "Molecular cloning and characterization of thermostable esterase and lipase from Geobacillus thermoleovorans YN isolated from desert soil in Egypt," Process Biochemistry, vol. 42(7), pp. 1090-1100, 2007.

[8] Christopher, P. Lew et al. "A thermo-alkaline lipase from a new thermophile Geobacillus thermodenitrificans AV-5 with potential application in biodiesel production," Journal of Chemical Technology \& Biotechnology 90.11 (2015): 2007-2016.

[9] B. Van Den Burg, "Extremophiles as a source for novel enzymes," Current opinion in microbiology, vol. 6(3), pp. 213-218, 2003.

[10] S.Ugras, "Characterization of a thermophilic lipase from bacillus licheniformis ht7 isolated from hayran thermal springs in giresun," Romanian Biotechnological Letters, 22(1), 12297-12306., 2017.

[11] Z. Burcu Bakir \& K.Metin, "Production and characterization of an alkaline lipase from thermophilic Anoxybacillus sp. HBB16., Chemical and biochemical engineering quarterly, 31(3), 303-312.,2017.

[12] D. W. Lee, Y. S. Koh, K. J. Kim, B. C. Kim, H. J. Choi, D. S. Kim \& Y. R. Pyun, "Isolation and characterization of a thermophilic lipase from Bacillus thermoleovorans ID-1,"FEMS Microbiology Letters, 179(2), 393-400.,1999.

[13] M. Kambourova, N. Kirilova, R. Mandeva \& A.Derekova, "Purification and properties of thermostable lipase from a thermophilic Bacillus stearothermophilus MC 7.,"Journal of Molecular Catalysis B: Enzymatic, 22(5-6), 307-313.,2003.

[14] B.T. Mohammad, H. I. Al Daghistani, A. Jaouani, S. Abdel-Latif, C. Kennes, "Isolation and characterization of thermophilic bacteria from Jordanian hot springs: Bacillus licheniformis and Thermomonas hydrothermalis isolates as potential producers of thermostable enzymes," International journal of microbiology, 2017. 
[15] B. Venkatesagowda, E. Ponugupaty, A. M. Barbosa and R.F. Dekker, "Solid-state fermentation of coconut kernel-cake as substrate for the production of lipases by the coconut kernelassociated fungus Lasiodiplodia theobromae VBE-1," Annals of microbiology, vol. 65(1), pp. 129-142, 2015.

[16] A. Kumar and S.S. Kanwar, "Lipase production in solid-state fermentation (SSF): recent developments and biotechnological applications," Dynamic Biochemistry, Process Biotechnology and Molecular Biology, vol. 6(1), pp. 13-27, 2012.

[17] D. K. Parihar, "Production of lipase utilizing linseed oilcake as fermentation substrate," Int. J. Sci. Environ. Technol, vol. 1(3), pp. 135-143, 2012.

[18] H. Alkan, Z. Baysal, F. Uyar and M. Dogru, "Production of lipase by a newly isolated Bacillus coagulans under solid-state fermentation using melon wastes," Applied biochemistry and biotechnology, vol. 136(2), pp. 183-192, 2007.

[19] A. N. Ferreira, D. D. S. Ribeiro, R. A. Santana, A. C. Santos Felix, L. D. G. Alvarez, E. D. O. Lima et al., " Production of lipase from Penicillium sp. using waste oils and Nopalea cochenillifera," Chem. Engi. Commun., vol. 204, pp. 1167-1173, 2017.

[20] D.Galabova, B.Tuleva, D.Spasova, "Permeabilization of Yarrowia lipolytica cells by triton X-100," Enzyme Microb. Technol. 8, 18-22, 1996.

[21] F. Hasan, A.Shah, A.Hameed, "Influence of culture conditions on lipase production by Bacillus sp. FH5," Annals Microbiol. 56, 247-252, 2006.

[22] E. Akbari, K. Beheshti-Maal, H.Nayeri, "Production and optimization of alkaline lipase by a novel psychrotolerant and halotolerant strain Planomicrobium okeanokoites ABN-IAUF2 isolated from Persian Gulf," Health Sci. 5, 139$148,2016$.

[23] D. Yanmis, M. O. Baltaci, M. Gulluce and A. Adiguzel, "Identification of thermophilic strains from geothermal areas in Turkey by using conventional and molecular techniques," Res J Biotechnol, vol. 10(1), pp. 39-45, 2015.

[24] M. O. Baltaci, B. Genc, S. Arslan, G. Adiguzel and A. Adiguzel, "Isolation and characterization of thermophilic bacteria from geothermal areas in Turkey and preliminary research on biotechnologically important enzyme production," Geomicrobiology journal, vol. 34(1), pp. 53-62, 2017.
[25] T. C. Hung, R. Giridhar, S. H. Chiou, W .T. $\mathrm{Wu}$,"Binary immobilization of Candida rugosa lipase on chitosan," J. Mol. Catal. B - Enzym, vol. 26, pp. 69-782003.

[26] M. Taskin and S. Erdal, "Production of carotenoids by Rhodotorula glutinis MT-5 in submerged fermentation using the extract from waste loquat kernels as substrate," Journal of the Science of Food and Agriculture, vol. 91(8), pp. 1440-1445, 2011.

[27] M. C. T. Damaso, M.A. Passianoto, S.C. Freitas, R. C. A. Lago and S. Couri, S., "Utilization of agroindustrial residues for lipase production by solid-state fermentation," Braz. J. Microbiol, vol. 39(4), pp. 66-70, 2008.

[28] L. Bora and M. Bora, "Optimization of extracellular thermophilic highly alkaline lipase from thermophilic Bacillus $\mathrm{sp}$ isolated from Hotspring of Arunachal Pradesh, India," Brazilian Journal of Microbiology, vol. 43(1), pp. 30-42, 2012.

[29] N. K. Saun, P. Mehta and R. Gupta, "Purification and physicochemical properties of lipase from thermophilic Bacillus aerius," Journal of oleo science, vol. 63(12), pp. 1261-1268, 2014.

[30] S. Dharmsthiti and S. Luchai, "Production, purification and characterization of thermophilic lipase from Bacillus sp. THL027," FEMS microbiology letters, vol. 179(2), pp. 241-246, 1999.

[31] M. Guncheva, D. Zhiryakova, "Catalytic properties and potential applications of Bacillus lipases," J. Mol. Catal. B: Enzym, vol. 68, pp. 1-21, 2011. 